OPEN ACCESS

Edited by:

David A. Gewirtz,

Virginia Commonwealth University,

United States

Reviewed by:

Ze-Chun Yuan,

University of Western Ontario, Canada

Gurumayum Jitendra Sharma,

Manipur University, India

*Correspondence:

Fuad Fares

ffares@sci.haifa.ac.il

Specialty section:

This article was submitted to

Pharmacology of Anti-Cancer Drugs,

a section of the journal

Frontiers in Oncology

Received: 08 January 2019

Accepted: 14 March 2019

Published: 10 April 2019

Citation:

Bar-Shalom R, Bergman M, Grossman S, Azzam N, Sharvit L and Fares $F$ (2019) Inula Viscosa Extract Inhibits Growth of Colorectal Cancer

Cells in vitro and in vivo Through

Induction of Apoptosis.

Front. Oncol. 9:227.

doi: 10.3389/fonc.2019.00227

\section{Inula Viscosa Extract Inhibits Growth of Colorectal Cancer Cells in vitro and in vivo Through Induction of Apoptosis}

\author{
Rinat Bar-Shalom ${ }^{1}$, Margalit Bergman ${ }^{2}$, Shlomo Grossman ${ }^{2}$, Naiel Azzam ${ }^{1}$, Lital Sharvit ${ }^{1}$ \\ and Fuad Fares ${ }^{1 *}$
}

${ }^{1}$ Department of Human Biology, Faculty of Natural Sciences, University of Haifa, Haifa, Israel, ${ }^{2}$ Faculty of Life Sciences, Bar-Ilan University, Ramat-Gan, Israel

Colorectal cancer $(\mathrm{CRC})$ is the second most common cancer in females and the third in males worldwide. Conventional therapy of CRC is limited by severe side effects and by the development of resistance. Therefore, additional therapies are needed in order to combat the problem of selectivity and drug resistance in CRC patients. Inula viscosa (IV) is a well-known medicinal perennial herb in traditional medicine. It is used for different therapeutic purposes, such as; topical anti-inflammatic, diuretic, hemostatic, antiseptic, antiphlogistic, and in the treatment of diabetes. Several studies attempted to reveal the anti-cancer activity of different extracts prepared by different organic solvents from different parts of the IV plant. The aim of the present study is to examine the potential beneficial effects of IV leaf aqueous extract on the growth of colon cancer cells in vitro and in vivo. The results indicated that exposure of colorectal cancer cells to IV extract, significantly reduced cell viability in a dose and time dependent manner. Moreover, treatment of cells with $300 \mu \mathrm{g} / \mathrm{ml}$ of IV extract induced apoptosis, as it was detected by Annexin V/FITC/PI, TUNEL assay, and the activation of caspases. In vivo studies revealed that treatment with 150 or $300 \mathrm{mg} / \mathrm{kg}$ IV extract inhibited tumor growth in mice transplanted with MC38 cells. Tumors' weight and volume were significantly $(P<0.001)$ reduced when compared to untreated-control group. Staining of the paraffin section of tumors revealed that IV treatment inhibited cell proliferation and induced apoptosis. Additionally, no side effects such as; weight loss, behavior changes, ruffled fur or changes in kidney, and liver functions were observed. These results may indicate that active doses of IV extract are not toxic. Further studies are needed in order to identify the structure of the active compounds. Results from this study may contribute to the development of new and efficient strategies for treatment of human colon cancer.

Keywords: Inula viscosa, extract, colorectal cancer, apoptosis, caspases

\section{INTRODUCTION}

Colorectal cancer (CRC) is the second most common cancer in females after breast cancer and the third most common cancer in males after lung and prostate cancers. In 2018, the global incidence of CRC in both sexes was $\sim 1.85$ million with 880,792 deaths worldwide (1). The first line of treatment for potentially curable CRC patients is surgery (2), which is performed in $\sim 80 \%$ 
of patients, while half of them will experience a recurrence of the disease (3). Adjuvant therapy, such as chemotherapy, is administered in order to prevent local recurrence or distant metastases. In patients with metastasis, chemotherapy is the mainstay with the goal of prolonging survival and to maintain quality of life (2). The effectiveness of chemotherapy has been limited by severe side effects and by the development of resistance $(4,5)$. Therefore, conventional chemotherapy has no consistent benefit in overall survival. Additional therapies are therefore needed in order to combat the problem of selectivity and drug resistance in CRC patients. Natural products are considered to have anticancer activity with high effectiveness and less toxicity (6). More than $60 \%$ of drugs, currently in use for cancer treatment, have been isolated from natural products and numerous of them obtained from plant sources (7). In addition, due to the vast use in traditional medicine, there has been a growing interest in the use of medicinal herbs as a potential candidate for new anticancer therapeutic drugs.

Inula viscosa (IV) (L.) Ait. (syn. Dittrichia viscosa Greuter) (Compositae) is a well-known medicinal perennial herb, native to the Mediterranean basin (Figure 1). It grows on hillslopes, damp habitats and roadsides (8). IV has sticky leaves with bright yellow flowers that bloom between August and November (9). In traditional medicine, IV is used as a remedy plant, that exhibits several medical uses such as; anti-inflammatory, antipyretic, and antimicrobial activity (10). Numerous studies have revealed the presence of different biologically active compounds in IV and their ability to induce apoptosis in cancer cells, including groups of phytochemicals such as polyphenols (11) and sesquiterpens (12). Among the polyphenols discovered, Danino et al. (9) isolated polyphenolic antioxidants from leaves of IV including seven derivatives from the caffeoylquinic acid (CQA) and dicaffeoylquinic acid (diCQA) family. There is a possibility for synergistic effects of these compounds in cancer treatment. This assumption, together with the need for novel therapeutic strategies of colon cancer, leads us to focus on investigating the anti-carcinogenic effects of IV leaf water extract on colon cancer cell growth in vitro and in vivo, and to elucidate the mechanism of its action. Therefore, the effects of IV extract on HCT116 and Colo320 cells of human origin colorectal cancer, were examined. Moreover, the potential beneficial effect of IV on tumor growth in vivo was evaluated using mice transplanted with MC38 cells that originated from mouse murine colon adenocarcinoma.

\section{MATERIALS AND METHODS}

\section{Crude Extract Preparation of Inula viscosa}

Fresh leaves of IV were collected from a field at Bar-Ilan University, Israel. The leaves were sun-dried for 2 days and for another 4 days at room temperature. The dried leaves were homogenized in distilled water in a ratio of $1: 8(\mathrm{w} / \mathrm{v})$. The homogenate was collected, filtered through Whathman No.1 filter paper and centrifuged at 20,000 x $\mathrm{g}$ for $10 \mathrm{~min}$. The supernatant was frozen in liquid nitrogen and dried in a lyophilizer $\left(0.07 \mathrm{mbar},-48^{\circ} \mathrm{C}\right)$. The resulting powdered extract was dissolved in water in order to obtain a $2 \% \mathrm{w} / \mathrm{v}$ solution.

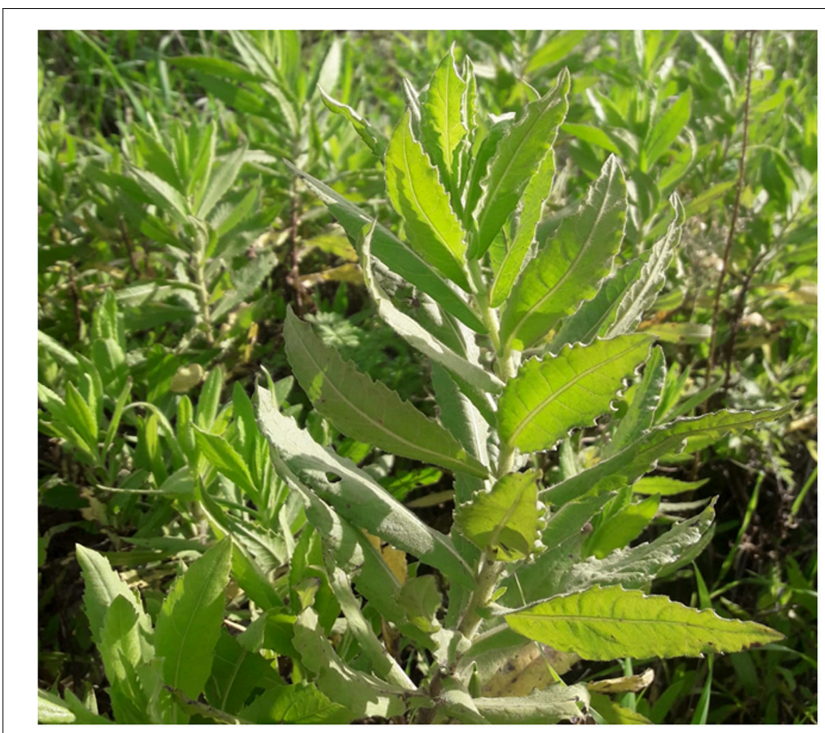

FIGURE 1 | Inula viscosa. Photograph of the plant, Inula viscosa. The photograph was taken from a field at Bar-llan University, Ramat-Gan, Israel.

\section{Cell Culture}

Human colorectal cancer cell lines; HCT116 (well differentiated) and Colo320 (poorly differentiated) and the mouse murine adenocarcinoma cell line (MC38) were purchased from American Type of Culture Collection (Bethesda, MD, USA). Normal primary liver fibroblasts were purchased from Cell Biologics (Chicago, IL, USA). HCT116 and MC38 were cultured in Dulbecco's modified Eagle medium (DMEM; $4.5 \mathrm{~g} / \mathrm{L} \mathrm{D}$ glucose) and Colo320 in RPMI-1640 medium. Normal primary liver fibroblasts were cultured in DMEM/F12 1:1 medium. Media were supplemented with $10 \%$ FBS, $1 \mathrm{mM}$ L-glutamine, and $1 \%$ penicillin-streptomycin. Cells were cultured in a humidified incubator at $37^{\circ} \mathrm{C}$ with $5 \% \mathrm{CO}_{2}$ saturation. The medium was changed every 3 days, and cells were passaged using Trypsin/EDTA. The cell lines were routinely tested for mycoplasma contamination with the Mycoplasma Test Kit EZ-PCR. All cell culture reagents, including Mycoplasma Test Kit, were supplied by Biological Industries (Kibbutz Beit Haemek, Israel).

\section{Cell Viability}

Cell proliferation was determined using the sodium 3'-[1-(phenylaminocarbonyl)-3,4-tetrazolium]-bis (4-methoxy6-nitro) benzene sulfonic acid hydrate (XTT) assay, according to the manufacturer's instructions (Biological Industries, Kibbutz Beit Haemek, Israel). In brief, cells were seeded in $100 \mu \mathrm{l}$ of medium, using 96-well plates at a cell density of 104 cells/well. After $24 \mathrm{~h}$, IV extract was added at different concentrations $(100-300 \mu \mathrm{g} / \mathrm{ml})$ and for varying time intervals $(24-72 \mathrm{~h})$. At least four independent experiments were performed each conducted in five replicates. Data are presented as the average proliferation percentage of the respective control. Based on the XTT experiments, IC50 values were calculated as the 
concentration of the plant extract that causes $50 \%$ inhibition in cell proliferation.

\section{Cytotoxicity Assay}

The Lactate dehydrogenase $(\mathrm{LDH})$ test was used to evaluate cytotoxicity of IV extract on colorectal cancer cells. LDH, a cytoplasmic enzyme, is rapidly released from the cells into the medium when the plasma membrane is damaged. The integrity of the plasma membrane following treatment was determined by measuring the LDH activity in the culture medium. Briefly, HCT116, Colo320, MC38, and normal primary liver fibroblasts cells were cultured in 96-well plates. IV extract was added in different concentrations. $24 \mathrm{~h}$ post treatment, the levels of $\mathrm{LDH}$ in the cell culture media were detected by the LDH Cytotoxicity Detection Kit PLUS (Roche, Mannheim, Germany) following the manufacturer's instructions.

\section{Cell Cycle Analysis}

In order to study the effect of IV extract on cell cycle progression, DNA content analysis was performed by Fluorescence Activated Cell Sorter (FACS) of 10,000 cells stained with propidium iodide (PI) as described previously (13). In brief, cells were cultured in $25 \mathrm{~cm}^{2}$ flasks and treated with $300 \mu \mathrm{g} / \mathrm{ml}$ of IV extract for 14 , 24,48 , or $72 \mathrm{~h}$. At the time of analysis, cells were trypsinized, harvested, and centrifuged at 2,000 rpm for $5 \mathrm{~min}$ at $4^{\circ} \mathrm{C}$. Cells were washed twice with cold PBS and then fixed in pre-chilled $70 \%$ ethanol at $-20^{\circ} \mathrm{C}$ for $1 \mathrm{~h}$. The cells were incubated with $0.1 \% \mathrm{NP}-40$ on ice for $5 \mathrm{~min}$, and subsequently washed twice with cold PBS, each time by centrifugation at 2,000 rpm for $5 \mathrm{~min}$ at $4{ }^{\circ} \mathrm{C}$. Then, $1 \mathrm{ml}$ of cold PBS containing RNase $(100 \mu \mathrm{g} / \mathrm{ml})$ was added to cells for $30 \mathrm{~min}$. Finally, $50 \mu \mathrm{g} / \mathrm{ml}$ of PI was added to cells followed by incubation for $20 \mathrm{~min}$ on ice. DNA content was examined by flow cytometry using a FACSCantoII with FACSDiva software (Becton Dickenson, San Jose, CA, USA).

\section{Annexin V-FITC/PI Double-Staining Assay}

Cell death was further analyzed by staining the cells with FITClabeled Annexin V and propedium iodide (PI) using an Annexin V-FITC apoptosis detection kit (MBL, Nagoya, Japan), according to the manufacturer's instructions. Briefly, cells $\left(2 \times 10^{5}\right)$ were seeded in $25 \mathrm{~cm}^{2}$ flasks and allowed to attach overnight. Cells were treated with $300 \mu \mathrm{g} / \mathrm{ml}$ of IV extract for $14,24,48$, or $72 \mathrm{~h}$. To detect early and late apoptosis, both adherent and floating cells were harvested together. Treated and untreated cells were harvested by trypsinization, washed, and suspended in ice-cold PBS. The washed cell pellet was suspended in icecold binding buffer containing FITC-conjugated Annexin V and PI. Samples were incubated in room temperature for $15 \mathrm{~min}$ in dark before analysis by FACSCantoII Flow cytometry (Becton Dickenson, San Jose, CA). The Annexin V-FITC-negative/PInegative population was considered to include all normal healthy cells. Annexin V-FITC-positive/PI negative cells were regarded as a measure of early apoptosis. The Annexin V-FITC-positive/PI positive cells were regarded as a measure of late apoptosis. The Annexin V-FITC-negative/PI-positive cells were considered to include necrotic cells. The percentage distributions of normal, early apoptotic, late apoptotic, and necrotic cells were calculated using FACSDiva software (Becton Dickenson, San Jose, CA).

\section{TUNEL Assay}

Apoptosis was confirmed by Terminal deoxynucleotidyl transferase dUTP nick end labeling (TUNEL) analysis using an in situ cell death detection kit (Roche, Mannheim Germany). Cells were seeded (30,000 cells) on chamber slides (Nunc, Denmark) and treated with $300 \mu \mathrm{g} / \mathrm{ml} \mathrm{IV} \mathrm{extract.} \mathrm{After} 48$ and $72 \mathrm{~h}$, cell morphology was examined using $4^{\prime}, 6$-diamidino2-phenylindole (DAPI) and TUNEL staining. At the end of treatment, cells were washed twice with PBS, fixed for $60 \mathrm{~min}$ with $4 \%$ paraformaldehyde and then permeabilized, using $0.1 \%$ Triton X-100 in $0.1 \%$ sodium citrate, to allow penetration of the TUNEL reaction reagents into the cell nucleus. TUNEL reaction mixture (TdT and fluorescein-dUTP) was added to label the fragmented DNA at $37^{\circ} \mathrm{C}$ for $1 \mathrm{~h}$ in humidified atmosphere in dark. After incubation time, cells were washed twice in PBS, and stained with DAPI solution in order to assess total cell number and for visualization of DNA morphology. Finally, the labeled DNA and the nucleus area were visualized by fluorescence microscopy (Nikon, Kawasaki, Japan).

\section{Western Blot Analysis}

Western blot analysis was performed for the assessment of Caspase-3, Caspase-8, Caspase-9, and PARP levels following treatment with $300 \mu \mathrm{g} / \mathrm{ml}$ of IV extract for $14,24,48$, or $72 \mathrm{~h}$. Cellular lysates were prepared by suspending $1 \times 10^{6}$ cells in glycerol lysis buffer (50 mM HEPES, $250 \mathrm{mM} \mathrm{Nacl}$, $0.5 \%$ NP-40, 2 mM EDTA, 10\% Glycerol) containing protease inhibitor cocktail (Roche, Mannheim, Germany). The lysates were centrifuged and the supernatants were collected. The protein concentrations were quantified using Bio-Rad protein assay based on the method of Bradford (14). Protein samples $(60 \mu \mathrm{g})$ were separated on $12 \%$ SDS-polyacrylamide gels and electro-transferred to a 0.45 microns pore size nitrocellulose membrane, using semi dry transfer. The membrane was blocked in 5\% non-fat dry milk in Tris-buffered saline and $0.1 \%$ Tween 20 (TBST) buffer and incubated with appropriate monoclonal primary antibodies: Anti-caspase 3; 1:5,000, Anticaspase $8 ; 1: 1,000$ (Abcam, Cambridge, UK), or polyclonal primary antibodies: human specific Anti-caspase 9; 1:1,000, PARP antibody; 1:1,000 (Cell Signaling Technology, MA, USA), in a blocking buffer overnight at $4^{\circ} \mathrm{C}$. After primary antibody incubation, the membrane was washed three times in TBST and incubated with appropriate secondary horseradish peroxidaseconjugated antibody (Jakson Immuno Research, USA) for $1 \mathrm{~h}$ at room temperature, followed by three washes with TBST. The membrane was developed using the EZ-ECL Chemiluminescence detection kit for HRP (Biological industries, Kibbutz Beit Haemek, Israel) and signals were observed and documented using gel imager ChemiDOcTMXRS Gel Documentation System (Bio-Rad, CA, USA). $\beta$-Actin (MP Biomedicals OH, USA) was detected on the same membrane and used as a loading control. Quantification of $\beta$-Actin normalized immunoblotting was carried out by densitometry using TotalLab TL120 graphic software (Non-linear Dynamycs LTD, NC, USA). 


\section{In vivo Studies}

\section{Animals}

The therapeutic activity of Inula viscosa extract was investigated using 6 week-old (20-25 g body weight) male C57BL/6 mice (Harlan Laboratories, Jerusalem, Israel). Mice were maintained in a standard cage (5 mice per cage) under sterile condition; with air filter tops and in a filtered laminar air flow room, temperature of $22^{\circ} \mathrm{C}$, and under $12 \mathrm{~h}$ light/dark schedule at the animal house at the Technion-Israel Institute of Technology (Haifa, Israel). Rodent diet (Koffolk Inc., Tel-Aviv, Israel) and tap water were autoclaved and provided ad libitum. The mice were kept in the animal facility at least 1 week before starting the experiments.

\section{In vivo Tumor Growth Assay}

MC38 cells $\left(10^{6}\right)$ suspended in DMEM medium $(0.2 \mathrm{ml})$ were injected subcutaneously (SC) into the right dorsal flank of the mice, using 25-gauge needle (Terumo scientific Inc.). When the tumor size reached about $100 \mathrm{~mm}^{3}$ (about 2 weeks after cell implantation), the animals were divided into 4 groups $(n=$ 8) (2 control and 2 treated groups). One group served as a control group that was not transplanted with M38 cells (control 1). Three groups were transplanted with M38 cells, while two groups were treated with 150 or $300 \mathrm{mg} / \mathrm{kg}$, and the third group was treated with PBS (control 2) by intraperitoneal (IP) injection. Treatments were conducted three times a week for 3-weeks and body weights and tumor volumes were measured biweekly. Body weights were measured using a weighing scale (Precisa, Switzerland) and tumor volumes were measured with digital caliper and calculated using the formula: length $x$ width $^{2} \times 0.52$, where width represents the shortest dimension of the tumor (15). At the end of treatment period, two mice from each group were taken to ultrasound imaging, and finally mice were sacrificed, tumors were surgically excised and their final weights and volumes were measured and tested for histological studies.

Blood samples were also collected from mice for analysis of liver and kidney functions.

\section{Ultrasound Imaging}

For ultrasound imaging, the VEVO 2100 high frequency ultrasound system (VisualSonic, Inc, Toronto, Canada) was used. Mice were anesthetized with $1.5 \%$ isoflurane in oxygen delivered via nose cone and allowed to breathe spontaneously. Mice were positioned on a feedback-controlled heating MousePad. The hair was shaved, in the area overlaying the tumor, with hair removal cream and pre-warmed ultrasound gel (ECO-MED Diagnostic Imaging, Canada) was applied on the skin of mice. Tumors were circled and measured using software incorporated in to the VEVO 2100 device.

\section{In situ Cell Analysis}

When the mice were sacrificed, tumors were excised and kept in formalin, and then paraffin blocks were prepared. Four micron sections were cut and fixed onto slides for Ki-67 staining and TUNEL assay.

\section{Ki-67 Staining}

$\mathrm{Ki}-67$ is as large nuclear protein, preferentially expressed during all active parts of the cell cycle (G1, S, and G2/M), but absent from resting cells $(\mathrm{G} 0)$. Cell proliferation in the tumors was analyzed by immunohistochemistry with formalin fixed section stained with anti-rat Ki-67 antigen antibody (DakoCytomation, Glostrup, Denmark), according to manufacturer instructions. Pre-treatment of tissue sections was performed using PT system (Dako, Glostrup, Denmark) and EnVision ${ }^{\mathrm{TM}}$ FLEX, High $\mathrm{pH}$ (Link) kit (Dako, Glostrup, Denmark). Briefly, Target Retrieval Solution (provided with the kit) was used at $97^{\circ} \mathrm{C}$ for $20 \mathrm{~min}$ and then at $60^{\circ} \mathrm{C}$ for more $20 \mathrm{~min}$. Slides were treated with peroxidase block (Envision FLEX Peroxidase-Blocking reagent, provided with the kit) for $5 \mathrm{~min}$, and rinsed with buffer for $5 \mathrm{~min}$. Primary rat Ki-67 antibody was applied at 1:50 dilution for $30 \mathrm{~min}$ at room temperature. Then, slides were rinsed twice for $5 \mathrm{~min}$ and secondary antibody (EmVision FLEX/HRP, provided with the kit) was applied at 1:300 dilutions. Slides were washed three times for $5 \mathrm{~min}$ in buffer and visualized using DAB + (provided with the kit) as chromagen and counterstained with hematoxylin.

\section{TUNEL Assay and DAPI Staining}

Paraffin-embedded sections of tumors were fixed in $4 \%$ paraformaldehyde and dewaxed. Briefly, slides were deparaffinized by heating at $60^{\circ} \mathrm{C}$ for $1 \mathrm{~h}$ in a hybridization oven. Next, slides were placed in a plastic slides holder and filled with W-CAP citrate buffer $\mathrm{pH}=6$ (Bio-Optica, Milan, Italy). The slides holder was placed in a water bath set to $65^{\circ} \mathrm{C}$ with shaking for $20 \mathrm{~min}$. Slides were washed twice with DDW for $5 \mathrm{~min}$ and stripped from proteins by incubation with $20 \mu \mathrm{g} / \mathrm{ml}$ proteinase K (PK) (Sigma-Aldrich Israel, Rehovot, Israel) for $15 \mathrm{~min}$ at room temperature, and then washed in DDW for $2 \mathrm{~min}$. TUNEL assay (Roche, Mannheim Germany) was performed according to the instructions by the manufacturer and stained with DAPI solution. At the end, slides were visualized by fluorescence microscopy.

\section{Statistical Analysis}

All experiments, except the in vivo studies, were repeated at least three times (unless indicated otherwise). All data were expressed as mean value \pm Standard Error (SE), and the statistical differences between groups were evaluated using Student's $t$-test for comparison between two groups or ANOVA test (or their non-parametric counterparts) for comparison between multiple groups. $P<0.05$ was considered statistically significant and the SPSS software was used for the calculation of differences.

\section{RESULTS}

\section{In vitro Studies Inhibition of Colon Cancer Cell Growth by Inula Viscosa Extract}

The results indicated that water extract of IV significantly $(P<0.001)$ decreased cell viability of HCT116 (Figure 2A) and Colo320 (Figure 2B) cells in a time and dose dependent manner. By contrast, cell viability of normal primary liver fibroblasts showed no significant change following treatment 
with IV extract, in comparison to untreated cells (Figure 2C). Cells were cultured in the presence of escalating concentrations of IV extract $(100-300 \mu \mathrm{g} / \mathrm{ml})$ on 96-wells for different times of treatment $(24-72 \mathrm{~h})$, and cell viability was measured by XTT assay (Figure 2). Cell viability, as measured for HCT116 (Figure 2A) was decreased by $18 \pm 1.88 \%, 48.2 \pm 7.77 \%$, and 52.3 $\pm 3.81 \%$ ( $p<0.001$ ) following 24,48 , and $72 \mathrm{~h}$ of treatment with $300 \mu \mathrm{g} / \mathrm{ml}$ of IV extract, respectively. Cell viability of Colo320 (Figure 2B) decreased by $19.35 \pm 1.5 \%, 51.2 \pm 1.97 \%$, and 60.89 $\pm 2.36 \%(p<0.001)$ following 24,48 , and $72 \mathrm{~h}$ of treatment with $300 \mu \mathrm{g} / \mathrm{ml}$ of IV extract, respectively. The IC $_{50}$ values were determined and found to be $\sim 300 \mu \mathrm{g} / \mathrm{ml}$ for both cell lines. For further in vitro experiments, the concentration of $300 \mu \mathrm{g} / \mathrm{ml}$ was chosen.

In order to exclude the possibility of cytotoxic effects of IV extract on the cells, Lactate dehydrogenase (LDH) leakage assay was performed. The assay detects the release of stable cytosolic enzyme LDH into the culture medium, due to cell membrane damage, as a result of cell lysis or injury, regardless to the type of cell death (16). Cells were treated with increasing doses (50$350 \mu \mathrm{g} / \mathrm{ml}$ ) of IV extract for $24 \mathrm{~h}$. It was observed that IV extract, at concentration of up to $350 \mu \mathrm{g} / \mathrm{ml}$ does not cause a statistically significant change in LDH level in the media, compared with untreated control cells (Data not shown).

\section{The Effect of Inula viscosa on Cell Cycle Progression}

In order to study the effect of IV extract on cell cycle progression, cells were incubated with $300 \mu \mathrm{g} / \mathrm{ml}$ of IV for 14-72 h (Figures 3, 4), and the distribution of cells in the different phases of cell cycle was determined by fluorescence activated cell sorter (FACS). The results indicated that exposure of HCT116 and Colo320 to $300 \mu \mathrm{g} / \mathrm{ml}$ of IV extract exerted inhibitory effects on the cell cycle progression in a time dependent manner. Exposure of HCT116 cells to IV extract resulted in an increased proportion of cells in the G2/M phase of the cell cycle after $14 \mathrm{~h}(P<0.01$; Figure 3A1) and $24 \mathrm{~h}(P<0.001$; Figure $3 \mathrm{A2})$ of treatment, as compared with untreated cells (control). Similarly, exposure of Colo320 cells to $300 \mu \mathrm{g} / \mathrm{ml}$ of IV extract resulted in an increased proportion of cells in G2/M phase following $14 \mathrm{~h}(P<0.05$; Figure 3B1 $)$ and no significant increase after $24 \mathrm{~h}$ (Figure 3B2) of treatment, as compared with the untreated cells. Extended periods of treatment (48 and $72 \mathrm{~h}$ ) caused cells to exit from G2/M phase toward the sub-G1 phase (Figure 4), indicating the possibility of induction of apoptosis (17). A significant increase of cell accumulation in sub-G1 phase compared to untreated cells, has been observed following 48 and $72 \mathrm{~h}$ of treatment, in both cell lines (HCT116, $48.47 \pm 5.67 \%$ vs. $5.54 \pm 1.52 \%$ after $72 \mathrm{~h}$; Colo320, $40.18 \pm$ $4.81 \%$ vs. $5.68 \pm 1.48 \%$, after 72 h, Figures $4 \mathbf{A}, \mathbf{B}$, respectively). This may indicate that exposure of the cells to IV extract for $48-72 \mathrm{~h}$ induces programed cell death.

\section{Treatment With IV Extract Induced Apoptosis in Colorectal Cancer Cells}

Annexin V-FITC and propodeum iodide (PI) staining were used in order to quantify the percentage of cells undergoing apoptosis, necrosis and viable cells. The apoptotic cells were counted as early apoptotic cells (quadrants Q2), late apoptotic cells (quadrants Q4), and represented as percentage of apoptotic cells (Figure 5) from total cell population. Figures 5A,B, indicate that treatment of HCT116 cells with $300 \mu \mathrm{g} / \mathrm{ml}$ of IV extract for 24,48 , or $72 \mathrm{~h}$ resulted in a significant increase of Annexin V by $2,4.2$, and 5.1 -folds, respectively. Similarly, treatment of Colo320 cells with $300 \mu \mathrm{g} / \mathrm{ml}$ of IV extract for $14,24,48$, or $72 \mathrm{~h}$ significantly increased Annexin V by 1.6, 3.16, 6.04, and 7.95folds, respectively, compared to control (Figures 5C,D). These results indicated that IV induces apoptosis on colorectal cancer cells. Terminal deoxynucleotidyl transferase dUTP nick end labeling (TUNEL) assay confirmed that exposure of the cells to IV extract induces apoptosis (Figure 6). HCT116 and Colo320 cells were grown in the absence or presence of $300 \mu \mathrm{g} / \mathrm{ml}$ of IV extract for 48-72 h. As shown in Figure 6, extensive DNA fragmentation was visible by fluorescence microscopy after TUNEL staining following treatment, compared to untreated cells.

\section{Inula viscosa Extract Activates Caspases}

To further investigate the mechanism of action of cell death induced by IV extract, a western blot analysis was performed to detect proteins that have been shown to be involved in both the extrinsic (caspase-8) and the intrinsic (caspase-9) apoptosis pathways. Data presented in Figure 7, showed that treatment of HCT116 cells with IV extract for $14-72 \mathrm{~h}$ activated caspase9 (Figure 7C), but not caspase 8 (Figure 7B), followed by activation of caspase-3 (Figure 7A) and cleavage of Poly (ADPribose) polymerase (PARP) (Figure 7D). This may suggest that IV induced apoptosis in HCT116 cells through the intrinsic pathway. Moreover, data presented in Figure 7 showed that treatment of Colo320 cells with IV extract for $14-72 \mathrm{~h}$ clearly activated caspase-8 (Figure 7B). In Figure 7C a gradual decrease of pro-caspase- 9 was seen, but not a clear cleavage. The activation of caspase-3 was well observed (Figure 7A) as well as the cleavage of PARP (Figure 7D). This may suggest that IV induced apoptosis in Colo320 cells through the extrinsic pathway and probably via the intrinsic pathway as well.

\section{In vivo Studies}

The effect of IV leaves water extract on tumor growth was examined on subcutaneously transplanted mouse tumor cell line, MC38, in C57BL/6 mice. Prior to preforming the in vivo experiments, the effects of IV on cell viability, cell proliferation, cytotoxic effects, and apoptosis induction were examined in vitro on MC38 cell line. The effects of IV extract on MC38 cells were similar to the results obtained with HCT116 and Colo320 cells.

\section{Inula viscosa Extract Inhibits Tumor Growth in Animals}

Animals were injected with MC38 cells subcutaneously into the flank. Two weeks after tumor formation, animals were treated intra-peritoneum (IP) with either PBS or IV extract (150 and $300 \mathrm{mg} / \mathrm{kg}$ ) three times a week for 3 weeks. Tumor volumes were measured twice a week. The results indicated that treatment with IV extract significantly $(P<0.001)$ decreased tumor growth in comparison to control group (Figure 8). While 


\section{A}

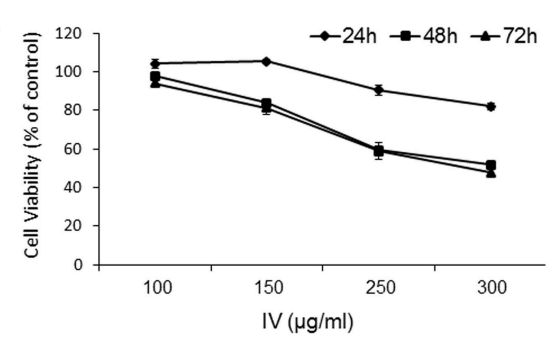

B $\left.{ }^{120}\right] \rightarrow-24 h \rightarrow-48 h \rightarrow 72 h$

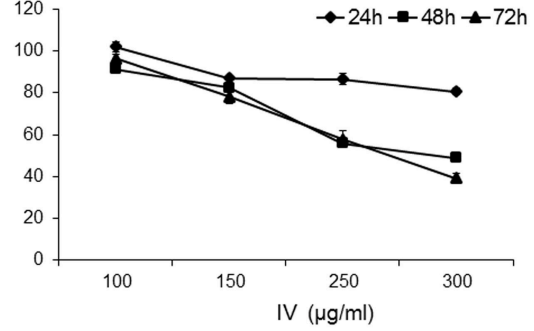

C

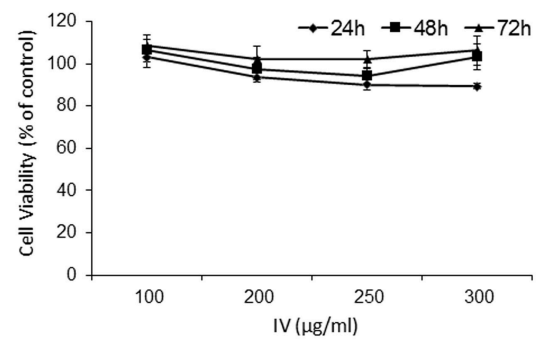

FIGURE 2 | IV treatment reduces cell viability of human colorectal cancer cells. HCT116 (A), Colo320 (B) cells, and normal primary liver fibroblasts (C) were treated with increasing concentrations of IV extract (100-300 $\mu \mathrm{g} / \mathrm{ml}$ ) for 24, 48, and $72 \mathrm{~h}$ and cell viability was determined using XTT assay as described under "Materials and Methods." The results are presented as the percentage of control and expressed as mean \pm SE of four independent experiments in which each treatment was performed in five replicates.

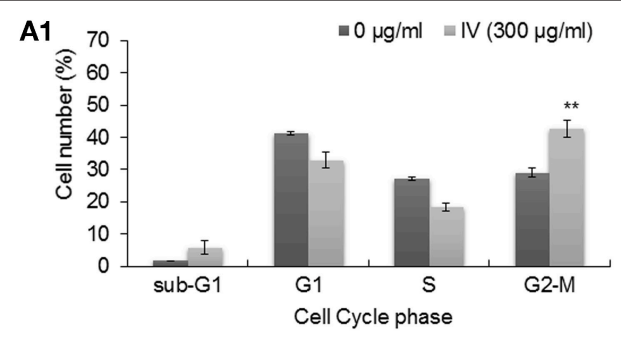

B1

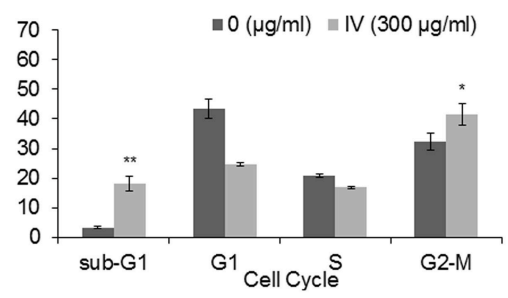

A2

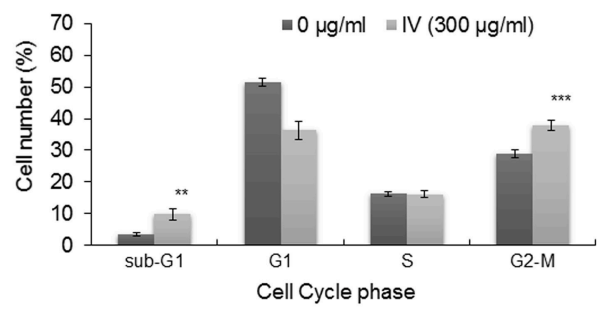

B2

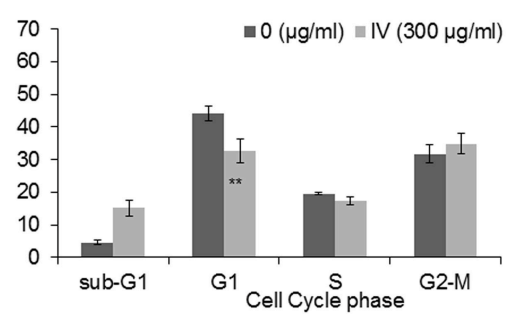

FIGURE 3 | Treatment with IV for 14-24 h resulted in cell cycle arrest at G2/M phase. HCT116 (A) and Colo320 (B) cells were treated with $300 \mu \mathrm{g} / \mathrm{ml}$ of IV extract for $14 \mathrm{~h}(\mathbf{A 1}, \mathbf{B} 1)$ and for $24 \mathrm{~h}$ (A2,B2) and subjected to cell cycle analysis by flow cytometry. The results are presented as mean \pm SE of five experiments each conducted in duplicates and are expressed as percentage from total 10,000 analyzed cells. Statistical significance was determined by a two-tailed student's t-test (treatment VS. control) and is indicated as ${ }^{*} p<0.05 ;{ }^{* *} p<0.01 ;{ }^{* \star *} p<0.001$.

the tumor volumes in the control group increased by $\sim 8.5$ folds over the treatment period, the tumor volumes of the treated group with $150-300 \mu \mathrm{g} / \mathrm{kg}$ IV were decreased by 1.9 and 1.2-folds, respectively. At the end of the treatment period (day 21), ultrasound imaging indicated that treatment with IV resulted in a reduction in situ of the tumors compared to control (Figure 9A). Figure 9B demonstrates representative samples of the tumors collected after scarifying the animals and dissection of the tumors. As can be seen, there is an enormous difference between the tumors from control and treated mice.

The results also indicated that the tumor weights (Figure 9C) and tumor volume (Figure 9D) were significantly $(P<$ $0.001)$ decreased.

In order to reveal any cytotoxic effect of IV extract in vivo, the average body weights of untreated and treated mice were measured every alternate day. The body weight did not 

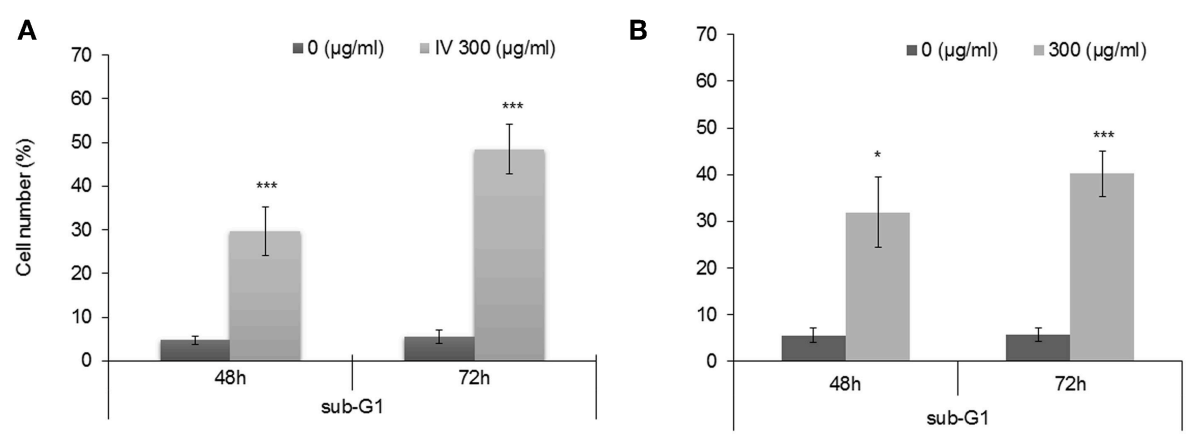

FIGURE 4 | Treatment with IV for 48-72 h resulted in accumulation of cells in Sub G1 phase of the cell cycle. HCT116 (A) and Colo320 (B) cells were treated with $300 \mu \mathrm{g} / \mathrm{ml}$ of IV extract for $48 \mathrm{~h}$ and for $72 \mathrm{~h}$ and subjected to cell cycle analysis by flow cytometry. Data are presented as mean \pm SE of five experiments, each conducted in duplicates and are expressed as percentage from total 10,000 analyzed cells. Statistical significance was determined by a two-tailed student's $t$-test (treatment vs. control) and is indicated as ${ }^{*} p<0.05 ;{ }^{* \star *} p<0.001$.

A

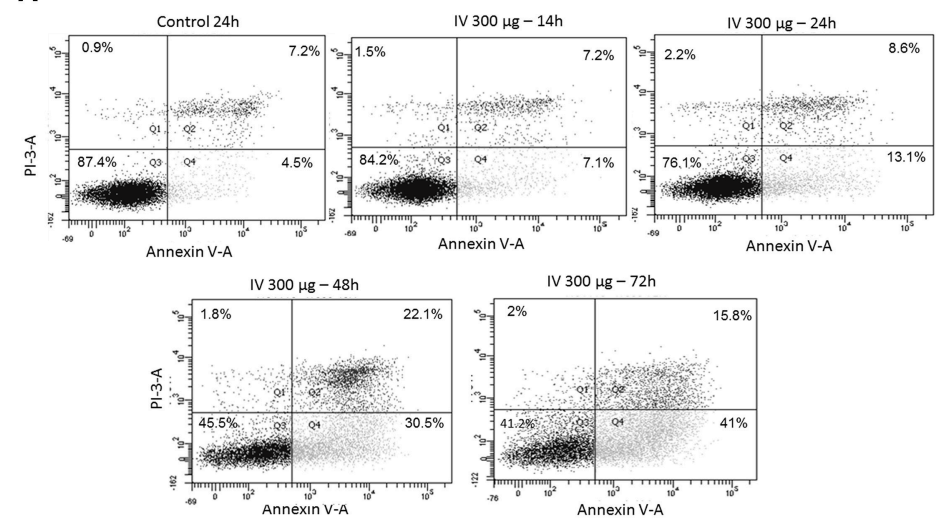

C
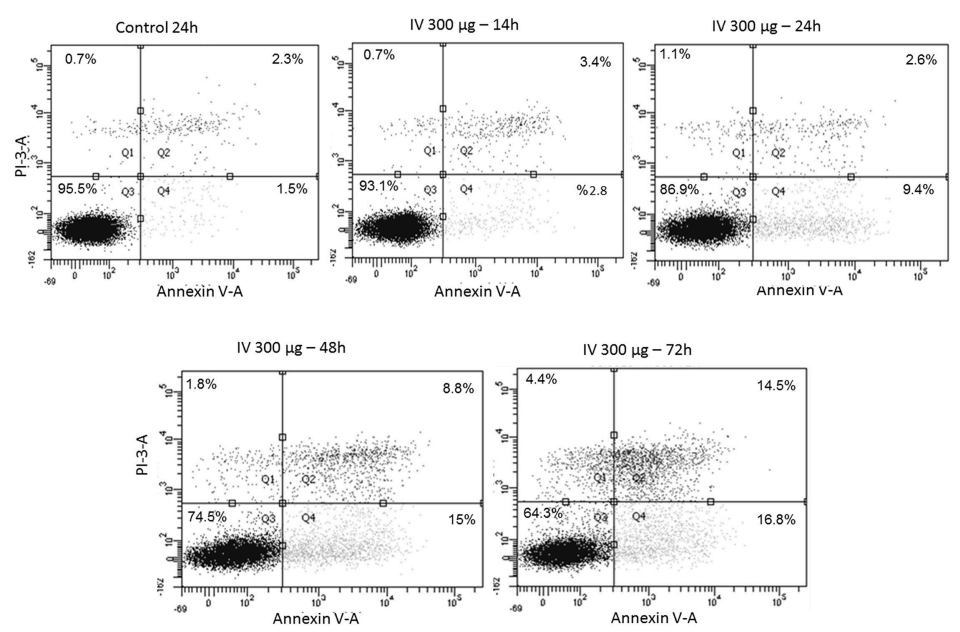

B

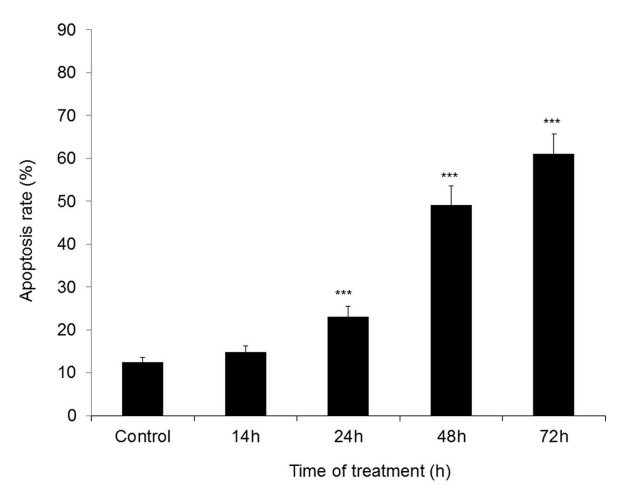

D

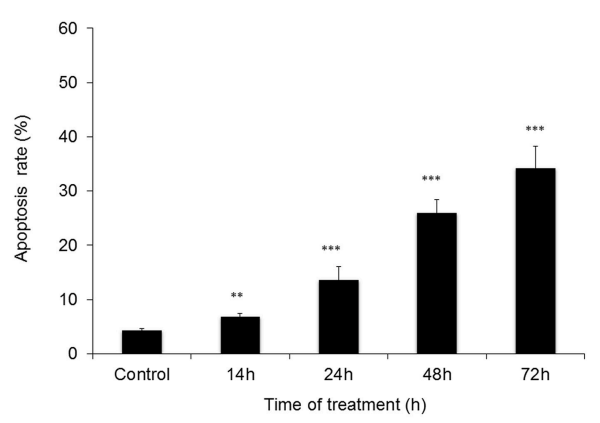

FIGURE 5 | Measurement of apoptotic cells using an Annexin V binding. HCT116 (A,B) and Colo320 (C,D) cells were treated with $300 \mu \mathrm{g} / \mathrm{ml} \mathrm{IV} \mathrm{for} \mathrm{14-72} \mathrm{h.} \mathrm{and} \mathrm{Flow}$ cytometric analysis of Annexin V-FITC/PI double-stained was performed. In each plot $(\mathbf{A}, \mathbf{C})$ the lower left quadrant (Q3) represents viable cells, the upper left quadrant (Q1) indicates necrotic cells, the lower right quadrant (Q4) denotes early apoptotic cells, and the upper right quadrant (Q2) represents necrotic or late apoptotic cells. Data are presented as mean \pm SE of five independent experiments, each conducted in duplicates [mean (Q2+Q4) \pm SE] (B,D). Statistical significance was determined by a two-tailed student's $t$-test [treatment vs. control (untreated cells)] and is indicated as ${ }^{\star \star} p<0.01 ;{ }^{\star \star \star} p<0.001$. 


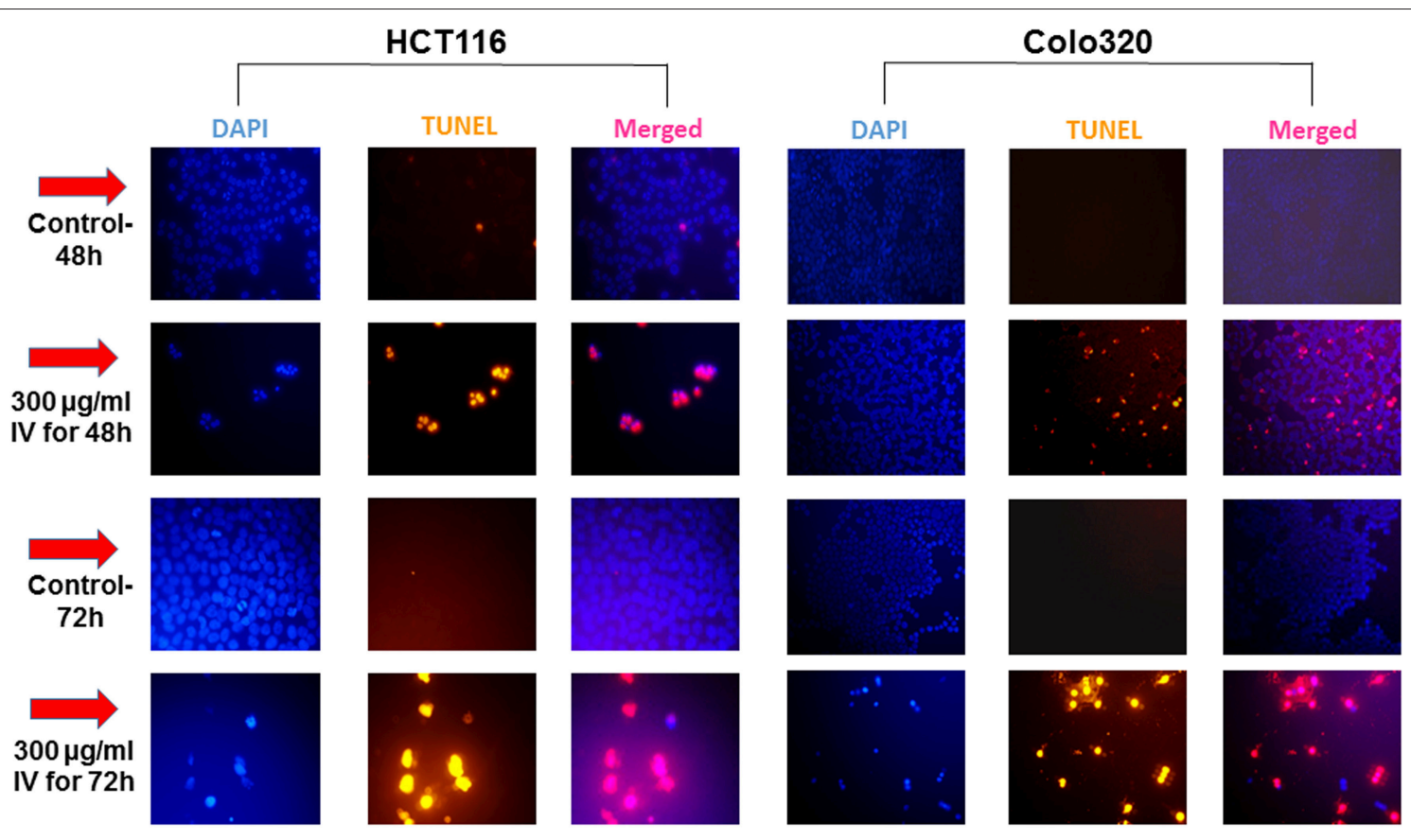

FIGURE 6 | IV treatment of colorectal cancer cells induced apoptosis. HCT116 and Colo320 cells were seeded in chamber slides and treated with $300 \mu \mathrm{g} / \mathrm{ml}$ IV extract for 48 or $72 \mathrm{~h}$. The cells were analyzed for apoptosis by TUNEL assay. Illustrations are representatives of three independent experiments, each conducted in duplicate. Blue-colored cells (DAPI dye) are living cells; red colored cells (fluorescence-labeled dUTP) are apoptotic cells. Cells were visualized by fluorescence microscopy (original magnification X20).

vary significantly throughout the study, according to Repeated Measures ANOVA test; $\left[F_{(6.744,62.944)}=0.727, P=0.645\right]$ (data not shown). Moreover, there were no observable signs of distress such as impaired movement, ruffled fur or change in behavior of IV-treated animals compared to controls. In addition, kidney and liver functions were measured in blood samples collected from control and treated animals at the end of the experiment following animal sacrificing. The results indicated that there was no significant difference in liver and kidney parameters that were measured in control and treated animals (Table 1).

\section{Inula viscosa Extract Inhibits Cell Proliferation and Induced Apoptosis of Colorectal Cancer Tumors in Mouse Model}

In order to better understand how IV extract affects tumor growth in vivo, tumors were collected, fixed in formalin, and sections were prepared for several histological staining. In order to examine the effect of IV extract on cell proliferation, cells were stained with Ki-67 antibody. The results indicated that the number of proliferating cells in the control specimens is larger than that seen in the specimens of treated animals (Figure 10A). This may indicate that IV treatment reduced tumor cell proliferation. In addition, the tumor specimens were stained with DAPI and TUNEL (Figure 10B). The results revealed that treatment with IV extract resulted in a morphological changes and induction of apoptosis.

These results strongly demonstrated that treatment with IV aqueous extract reduced cell proliferation and induced apoptosis of colon cancer cells that resulted in the inhibition of tumor growth in the allograft mice model.

\section{DISCUSSION}

The treatment of cancer over the past decades has relied primarily on the use of various forms of cytotoxic chemotherapy and radiation therapy. The effectiveness of cytotoxic treatments has been limited by the side effects and by the development of resistance. In order to combat the problem of side effects, selectivity, and drug resistance, new effective drugs are needed for CRC treatment. Natural products are a source of anticancer drugs which frequently seem to be more effective and/or less toxic (6). Approximately $60 \%$ of drugs that are currently in use for cancer treatment, have been isolated from natural products and many of them are derived from plants (18). In many countries around the world, medicinal plant extracts constitute a common alternative for cancer treatment, with no toxicity (19).

The present study was undertaken to evaluate the anticancer effects of Inula viscosa (IV) leaf water extract, on the growth of human colorectal cancer cells in vitro, and on tumor growth in vivo using a xenograft mouse model.

The extract showed profound anti-cancer effects on two human colorectal cancer cell lines; HCT116 and Colo320. Cell viability was significantly reduced following exposure to IV extract in a time and dose dependent manner with $\mathrm{IC}_{50}$ of $\sim 300 \mu \mathrm{g} / \mathrm{ml}$ without affecting LDH release.

Different solvents used for IV extractions revealed different molecules present in the extract with dependency to the solvents 
A

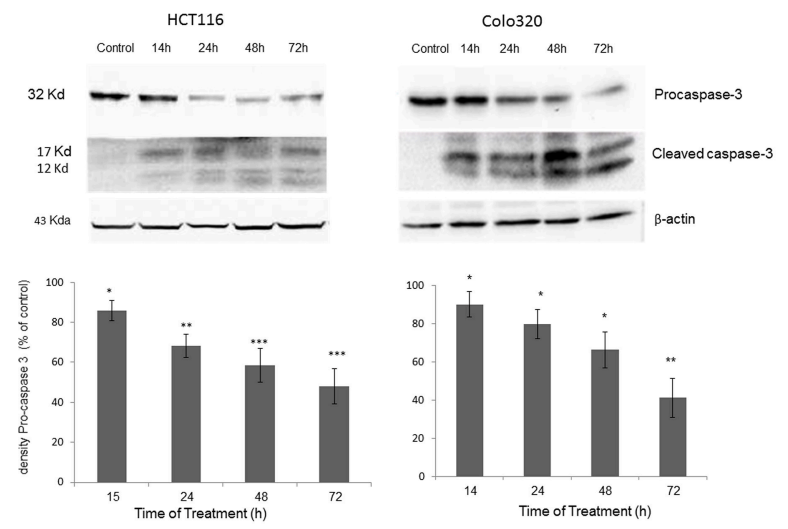

C
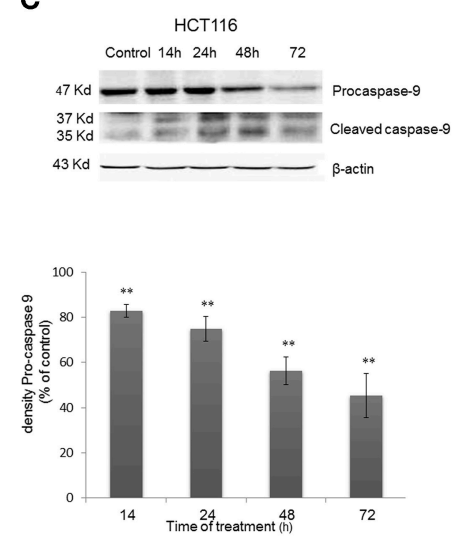

B
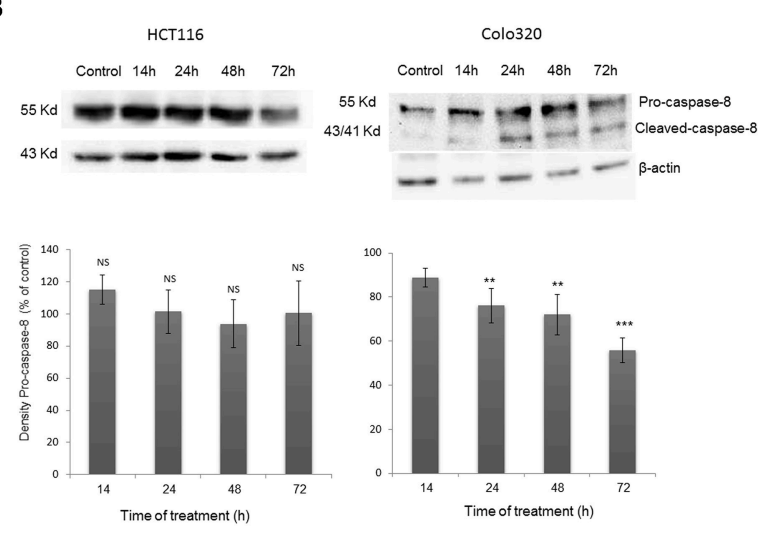

D
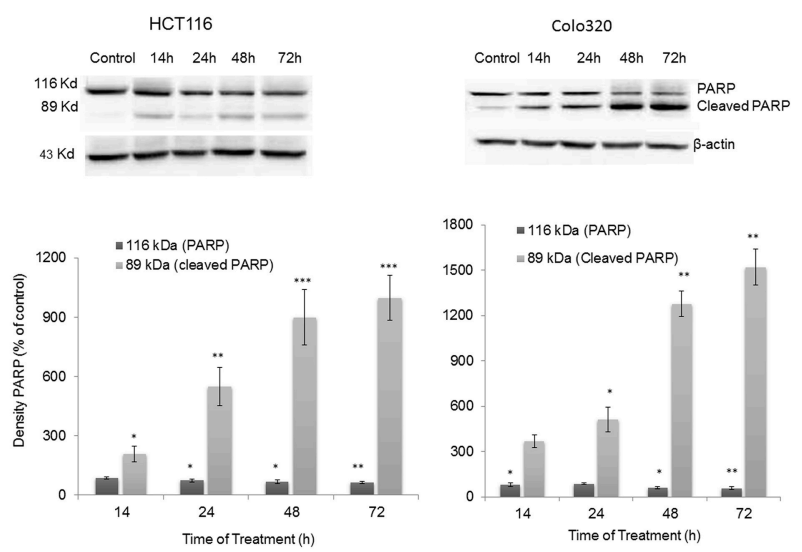

FIGURE 7 | Activation of Caspases following IV treatment. HCT116 and Colo320 cells were treated with 300 $\mu \mathrm{g} / \mathrm{ml}$ IV extract for $14-72 \mathrm{~h}$. and caspase-3 (A), caspase-8 (B), caspase-9 (C), and PARP (D) were detected by Western blot, where $\beta$-Actin was used as loading control. Densitometry analysis represents the average expression levels of the pro-caspase and/or the cleaved caspase and PARP; Density values were calculated as a control from the proper $\beta$-actin and as a percent of control. Data represented are average of three independent experiments (mean \pm SE). Statistical significance was determined by a two-tailed student's $t$-test (treatment vs. control) and marked as ${ }^{\star} p<0.05$, ${ }^{\star *} p<0.01,{ }^{\star \star *} p<0.001$; NS, Not Significance.

used. For example, a recent study revealed the presence of 51 compounds, including 11 phenolic acids, 23 flavonoids, one lignin, and 12 terpenoids in ethanol extract of IV leaves. Twenty six of these compounds were described for the first time in IV (20). Several studies have shown the anti-proliferative activity of IV extracted from different parts of the plant and by different solvents. Previous works reported that in vitro proliferation of breast cancer cells, MCF-7, was decreased after exposure to flower IV extracts, derived by different solvents (11). Other studies, have demonstrated the cytotoxic effect of hexanic extract of IV leaves on human cervical carcinoma cell lines, in vitro $(21,22)$.

In the present study, we report the anti-proliferative activity of water extract from IV leaves on human colorectal cancer cells. Inula viscosa leaves are known to contain many biological active compounds (23), including polyphenols such as phenolic acids that seem to be the most abundent group of polyphenols in IV leaves (24). Some of the polyphenol classes found in IV leaves are flavonoids, terpens, lactones $(9,10,25,26)$, and sesquiterpens acids such as Tomentosin and Inuvisocolide (12).
Polyphenol fraction from IV leaves was recently investigated, by Brahmi-Chendoyh et al. (27) and was found to be rich in caffeoyl shikimic acids and unusual dihydrobenzofuran ligands as main secondary metabolites. Moreover, 43 secondary metabolites were identified in this fraction (27). The process of carcinogenesis might be stopped or delayed by exposure to phytochemicals via diet or pharmacological administration (28). For instance, phytochemicals are thought to potentially have a role in reducing the incidence of colon cancer (29). The Polyphenols, including flavonoids and phenolic acid, and sesquiterpens, are noted for their ability to induce apoptosis in colon cancer cells $(30,31)$. Moreover, high levels of reactive oxygen species (ROS) cause several disorders including progression of multiple cancers, including colorectal cancer (32). It is well known that the main role of antioxidants is to protect against damage caused by ROS, leading to a reduction of cancer risk $(32,33)$. Extract from IV leaves was found to have antioxidant activity as well as polyphenols, such as 1,3-dicaffeoylquinic acid and more different derivatives of dicaffeoylquinic acid and caffeoylquinic acid. (9, 


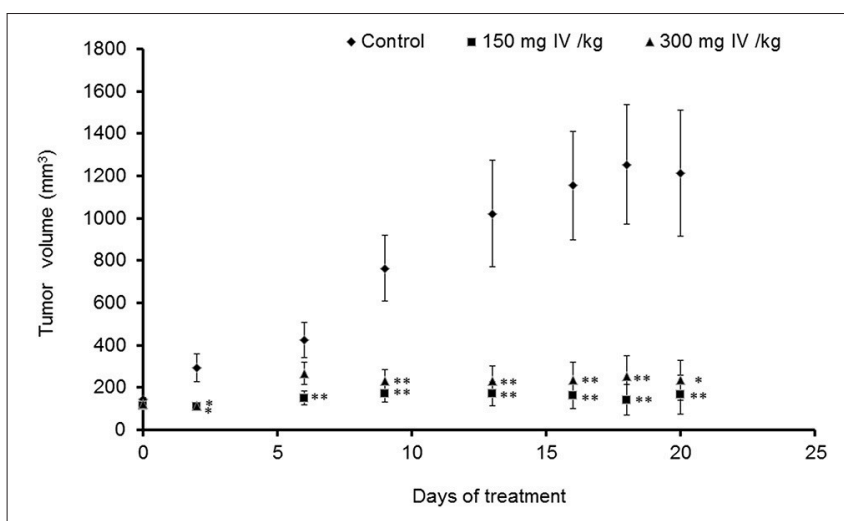

FIGURE 8 | IV extract inhibited tumor growth of colon cancer cells in mice. C57BL/C male mice were subcutaneously (SC) implanted with $1 \times 10^{6}$ MC38 cells. When the tumors reached a volume of $100 \mathrm{~mm}^{3}$, mice were treated 3 times a week by intraperitoneal injection (IP) of either PBS $\times 1$ to the control group, or IV extract, (150 or 300 mg/kg body weight) for 3 weeks, as described under "Materials and Methods." During the experiments, tumor volumes were measured twice a week using caliber meter. The results are presented as the mean \pm SE. $n=8$ mice per experimental group. Statistical significance was determined by a two-tailed student's $t$-test (treatment vs. control in each time point) and assigned as ${ }^{*} p<0.05$, ${ }^{* *} p<0.01$ and by Repeated Measures ANOVA with Tukey HSD post hoc test for the evaluation of changes in tumor volumes over time in each group and for differences between control and treatment groups.

27). It is well known that the main role of antioxidants found in nutraceuticals is to protect the cells from damage caused by reactive oxygen species (ROS) and reducing cancer risk $(32,33)$. In light of these findings, it can be assumed that the leaf extract of Inula viscosa contains a diversity of active compounds, which exhibit a synergetic or at least, an additive anti-tumor effect on colorectal cancer cells.

The results of the present study indicated that IV extract induces cell cycle arrest at G2/M-phase followed by accumulation of cells in sub-G1 phase. We assume that IV extract induces apoptosis of colorectal cancer cells. Previous studies have demonstrated that there is a link between cell cycle regulation and cancer progression. Therefore, management of cancer can be achieved by targeting and inhibiting the cell cycle progression (34).

The results in the present study are compatible with those of other studies; Belayachi et al. (35) revealed that exposure of PC3 prostate cancer cells in culture to dichloromethane extract or hexanic extract of Inula viscosa, resulted in induction of G2/M arrest, which was detectable at $24 \mathrm{~h}$ of treatment and enhanced after $48 \mathrm{~h}$. However, treatment of SW620-colon cancer cells with the same extracts for $48 \mathrm{~h}$ caused cell cycle arrest in G1 phase and an increase in the sub-G1 population (35). In addition, Tomentosin and Inuviscolide, two isolated compounds from the Inula viscosa leaf extract, induced cell cycle arrest in melanoma cells at the G2/M phase following $4 \mathrm{~h}$ of treatment. Prolonging the exposure time to $24 \mathrm{~h}$ resulted in a profound peak at the G2/M phase and after extended periods of time, a profound accumulation of cells in sub-G1 phase was observed (12).

Many anticancer drugs act by blocking one or more stages of the cell cycle and finally trigger apoptosis (36). The G2/M phase accumulation is often related to induction of apoptosis in p53 functioning cell lines (37). p53 is a tumor suppressor gene that functions especially as a transcription factor by activating and down regulating gene expression, leading to cell cycle arrest or apoptosis (38). Fischer and colleagues found an involvement of 210 genes regulating G2/M cell cycle, at HCT116 cells, by the discovered p53-p21-DREAM-CDE/CHR pathway. Down regulations of most of these genes, seems to be a major mechanism for the G2/M cell cycle arrest by p53 (38). This may stand also for the G2/M arrest in our experiments in HCT116 cells, but more studies are required to confirm the involvement of p53. Since Colo320 cells are p53 mutant (39), we assume that the activity of IV aqueous extract is exerted in different pathway, which still needs to be explored.

The Annexin-V/PI and TUNEL assays confirmed that the decrease in cell viability was a result of apoptotic processes induced by IV treatment, where the cell cycle arrest was an intermediate stage before apoptotic death (as finally appeared in Sub-G1 ascent). Extension of treatment periods (48-72 h) with IV increases the apoptosis rate in both cell lines. The most obvious characteristics of apoptosis are cytoplasmic and nuclear condensation followed by inter-nucleosomal DNA cleavage, membrane blobbing, and finally cell damage (16). These hallmarks of apoptotic process were observed in the present study.

In most cases, anticancer therapies ultimately result in activation of caspases (40) which play a crucial role in the execution of apoptosis. In the present study, we examined caspase- 3 activation at various time points by western blotting analysis, using a polyclonal antibody specific for procaspase3 and the subunits $\mathrm{p} 12$ and p17. According to the results obtained, IV extract induced caspase- 3 activation in both cell lines. Caspase- 3 was detectable at $14 \mathrm{~h}$ after incubation with IV extract and levels of procaspase-3 significantly decreased in a time dependent manner in both cell lines, following treatment.

Subsequently to caspase-3 activation, cleavage of the active form of PARP, which stands for cell survival, is a critical step in the completion of the apoptotic program. Western blot analysis revealed that treatment with IV extract leads to cleavage of PARP in both cell lines in a time dependent manner. The results are correlated with results obtained for caspase-3, in a sense that at all time points at which caspase- 3 was activated, PARP was cleaved. These results strengthen the fact that caspase- 3 is responsible for the cleavage of PARP during cell death process (41).

In order to reveal whether the apoptotic process occurred through the extrinsic or intrinsic pathway, activation of caspase8 and caspase- 9 was assayed. Interestingly, the results indicated that treatment with IV activated caspase-9 in HCT116, the well differentiated cells, and caspases- 8 and probably- 9 in colo320 cells, the poorly differentiated cells. These findings may indicate that IV extract induces apoptosis through the intrinsic mitochondrial pathway in well differentiated cells and through both, the intrinsic and extrinsic pathways, in poorly differentiated cells.

The utilization of both extrinsic and intrinsic mechanisms to execute apoptosis can be reasoned by the existing crosstalk between both apoptotic pathways, as described previously by 

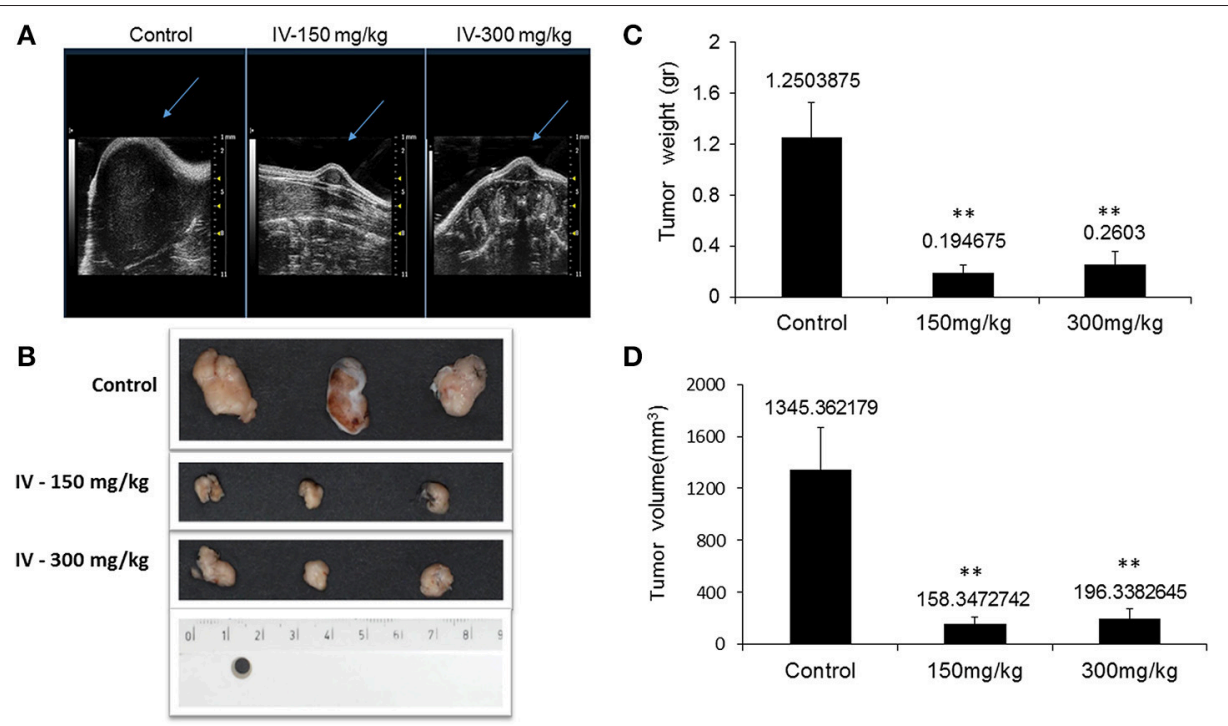

FIGURE 9 | IV aqueous extract suppressed tumor growth. Mice were anesthetized with 1.5\% isoflurane in oxygen delivered via nose cone and allowed to breathe spontaneously. Ultrasound imaging was performed using the VEVO 2100 high frequency ultrasound system (A). At the end of the treatment period, mice were sacrificed, tumors were isolated and pictures of the tumors from control or treated (150 or $300 \mathrm{mg}$ IV extract per kg) groups were taken (B) and the final tumor weights (C) and volumes (D) were measured. The results are presented as the mean \pm SE of $n=8$ tumors per experimental group. Statistical significance for tumor weight was determined by Mann-Whitney and for tumor volume by two-tailed Student's $t$-test (treatment vs. control). ${ }^{\star *} p<0.01$.

TABLE 1 | IV extract did not affect kidney and liver functions.

\begin{tabular}{|c|c|c|c|c|c|c|}
\hline Serum chemistry & Control 1 & Control 2 & IV 150 mg/kg & IV 300 mg/kg & $p$-value (1) & $p$-value (2) \\
\hline \multicolumn{7}{|c|}{ KIDNEY FUNCTION } \\
\hline UREL (mg/dL) & $47 \pm 3.78$ & $55.6 \pm 5.87$ & $51.5 \pm 2.13$ & $48.7 \pm 2.61$ & 0.43 & 0.231 \\
\hline NA-I (mmol/L) & $156.96 \pm 8.95$ & $152.32 \pm 0.52$ & $151.48 \pm 1.39$ & $151.23 \pm 1.55$ & 0.687 & 0.638 \\
\hline $\mathrm{CA}(\mathrm{mg} / \mathrm{dL})$ & $8.74 \pm 0.55$ & $11.15 \pm 0.28$ & $10.80 \pm 0.19$ & $10.5 \pm 0.28$ & 0.317 & 0.175 \\
\hline $\mathrm{K}-\mathrm{I}(\mathrm{mmol} / \mathrm{L})$ & $14.64 \pm 17.69$ & $7.39 \pm 0.62$ & $9.09 \pm 0.75$ & $8.80 \pm 0.69$ & 0.167 & 0.217 \\
\hline Creatinine (mg/dL) & $<0.2$ & $<0.2$ & $<0.2$ & $<0.2$ & & \\
\hline \multicolumn{7}{|l|}{ LIVER FUNCTION } \\
\hline $\mathrm{ALT}(\mathrm{u} / \mathrm{l})$ & $59.78 \pm 9.39$ & $99.28 \pm 41.39$ & $114.82 \pm 63.53$ & $67.48 \pm 12.81$ & 0.756 & 0.569 \\
\hline ALP2L (U/L) & $64 \pm 8.84$ & $87 \pm 3.86$ & $85 \pm 10.86$ & $77.11 \pm 6.29$ & 0.865 & 0.206 \\
\hline AST (U/L) & $323.94 \pm 71.4$ & $244.16 \pm 64.4$ & $269.30 \pm 68.8$ & $380.15 \pm 87.3$ & 0.803 & 0.309 \\
\hline GGTI (U/L) & $6.9 \pm 1.68$ & $0.32 \pm 0.25$ & $1.28 \pm 0.67$ & $3.37 \pm 2.92$ & 0.331 & 0.486 \\
\hline
\end{tabular}

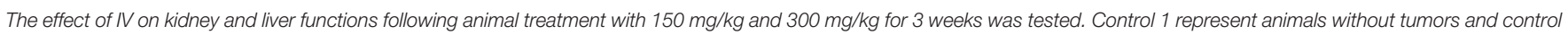

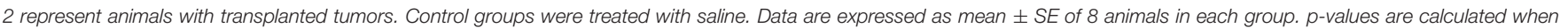
comparing IV treated $150 \mathrm{mg} / \mathrm{kg}$ [p-value (1)] or $300 \mathrm{mg} / \mathrm{kg}$ [p- value (2)] with untreated mice. Statistical significance was determined by two-tailed student's t-test or Mann-Whitney.

Fulda and Debatin (40). Binding of apoptotic signals causes activation of the extrinsic pathway, including Caspase- 8 which activates factors such as Bid. The activated Bid can translocate to the mitochondria and activate the intrinsic pathway, causing initiation of Caspase-9 activity. Activation of Caspases- 8 and-9 leads to activation of Caspase- 3 which executes the apoptotic process.

Other studies have shown that plant extracts can induce apoptosis through both apoptotic pathways. Lan et al. (42) revealed that a methanolic extract from the Emilia sonchifolia plant stimulated the activities of caspases-3,-8, and-9 and promoted the mitochondria-dependent and death receptor-associatedi protein levels in HCT116 cell line
(38). Moreover, treatment of HCT116, SW620, and SW480 colorectal cancer cell lines with Grape seed extract resulted in induced cleavage of caspases $-3,-8,-9$, and PARP. In addition, cytochrome-c was released from the mitochondria of all these three cell lines, suggesting the involvement of both pathways in the apoptotic death (43). To better understand the mechanism of IV induced cell death, additional studies are required.

In the present study, we have demonstrated that IV extract has a potential beneficial effect on the inhibition of tumor growth of subcutaneously transplanted MC38 cells in mice. Treatment with $150-300 \mathrm{mg} / \mathrm{kg}$ of IV three times a week for 3 weeks resulted in inhibition of tumor growth compared to controls. Immunohistochemical and histological studies indicated that IV 

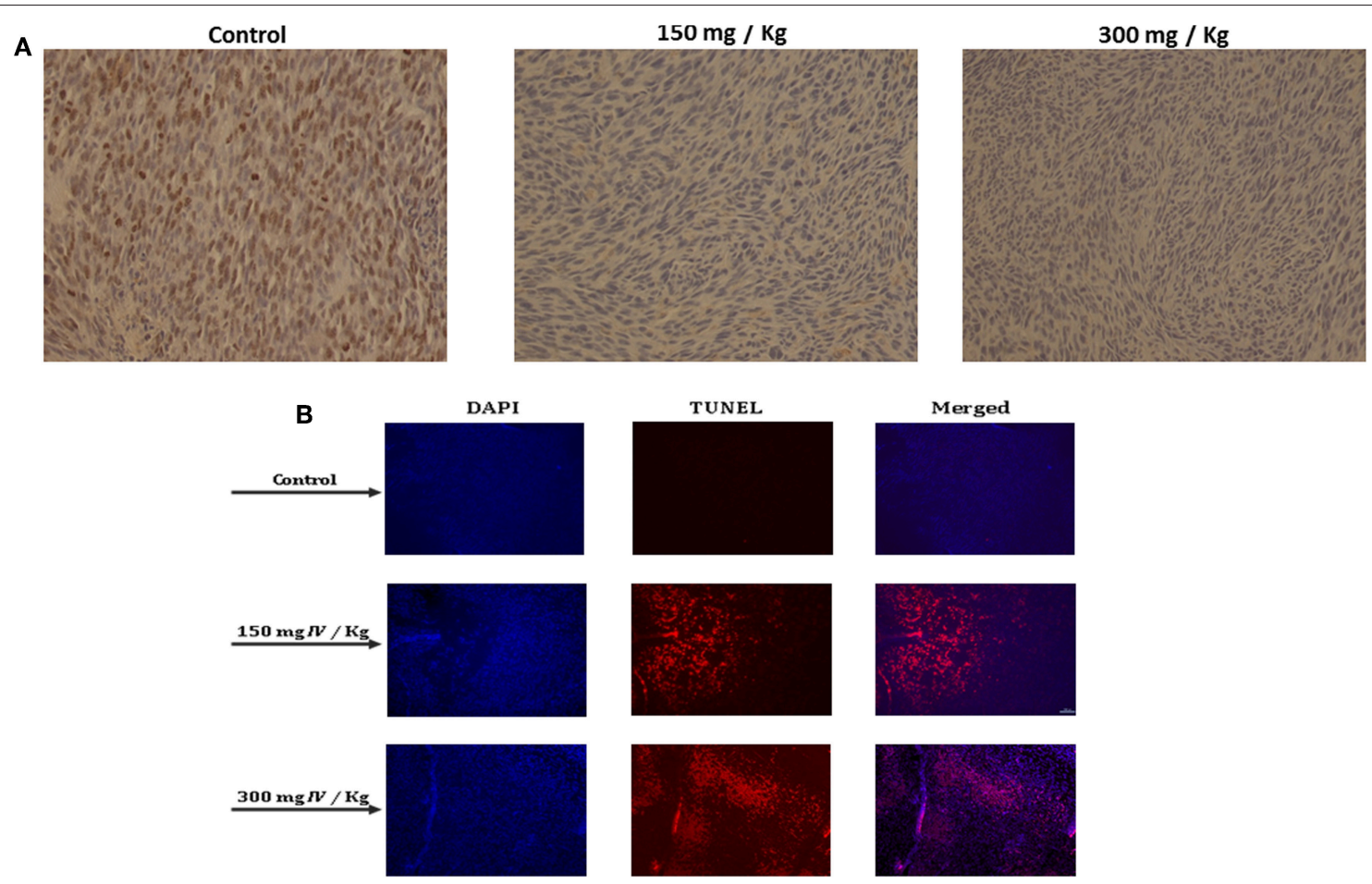

FIGURE 10 | IV inhibited cell proliferation and induced apoptosis in transplanted tumors in mice. Paraffin-embedded tissue sections were prepared from the tumor tissues and the (A) proliferation profiles of the cells were measured by detection of Ki-67. The images are representatives of the results obtained from control and treatment groups (Magnification, 200X). (B) DAPI and TUNEL staining of tumor sections. Tumors tissues were stained with DAPI and TUNEL and analyzed under a fluorescent microscopy. The TUNEL positive (shining orange) cells are apoptotic cells, nuclei are labeled with DAPI (blue) and the merge between DAPI and TUNEL appears pink (Magnification, 200X).

inhibits cell proliferation and induces apoptosis in the tumor cells. On the other hand, treatment with IV extract does not affect body weight and kidney and liver functions. Therefore, it is possible to assume that IV extract is safe and effective in cancer treatment.

To the best of our knowledge, no studies in the literature were found that examine any antitumor effect in vivo of any extract from the species of Inula. However, numerous studies have evaluated the potential anticancer effects of isolated compounds from the genus Inula, in vivo; Bigelovin, a sesquiterpene lactone isolated from Inula helianthus aquatica, has been proven to induce apoptosis in CRC through activation of downstream caspase leading to G2/M arrest and DNA damage. Moreover, this compound exhibited potent anti-tumor activities against $\mathrm{CRC}$ in vitro and in vivo (44). Another sesquiterpen, Japonicone A, a dimeric sesquiterpene lactone, isolated from traditional herb Inula japonica, has shown potent in vitro and in vivo anti-tumor activity against Burkitt's lymphoma (45). Flavonoids, a group of polyphenols found in several medical plants, also exhibited antitumor activity in vivo in different human cancer cells including CRC cells $(46,47)$. Interestingly, flavonoids can interact synergistically with other polyphenols in the treatment of cancer to induce apoptosis (30). As mentioned above, Inula viscosa leaves contain, among other compounds, sesquiterpens, flavonoids and phenols with proven anticancer activity in vivo.
These data, together with our in vivo results, strengthen the assumption that the different compounds composing the extract probably have a synergistic effect on the pronounced inhibition of tumor growth in mice.

Interestingly, in the present study, no side effects such as weight loss, kidney and liver functions and behavioral changes were observed. It is worth mentioning that, chemotherapeutic agents can produce a variety of acute and chronic organ toxicities including to the liver and kidneys $(48,49)$. Liver dysfunction under chemotherapy mainly consists of abnormal biologic liver tests indicating chronic cholestasis with elevation in the levels of Alkaline phosphatase (ALP) (49). Under chemotherapy up to $85 \%$ of patients develop fatty liver and in the more serious event this condition is accompanied by an increase in bilirubin levels. In addition, repeated chemotherapy induces irreversible hepatocellular damage through recruitment of inflammatory cells (49). More specifically, treatment of patients suffering from metastatic colorectal cancer with oxaliplatin, was strongly correlated to the development of sinusoidal injury in the liver (50). Since many antitumor drugs and their metabolites are cleared via the renal system, the kidneys are exposed to injury (48). Plasma creatinine levels serve as an index of endogenous renal function, with normal values below $0.2 \mathrm{mg} / \mathrm{dL}$ in normal mice (51). In the present study, this index did not change compared with control groups $(<0.2 \mathrm{mg} / \mathrm{dL})$. 
In conclusion, the present study indicated that IV aqueous leaf extract, affects the cell cycle progression and induces apoptosis by activation of caspases in colon cancer cells. Moreover, IV extract exhibits anti-tumor activities in an animal model, and it is safe for use. It can be suggested that IV aqueous leaf extract may serve as a strong potential drug for the treatment and probably for prevention of cancer.

\section{ETHICS STATEMENT}

All the experimental animal studies were conducted in accordance with the valid international guidelines after approval by the Animal Ethics Committee at the Technion Institute (Haifa, Israel) (Ethics number IL1481110).

\section{REFERENCES}

1. Ferlay J, Colombet M, Soerjomataram I, Mathers C, Parkin DM, Piñeros $\mathrm{M}$, et al. Estimating the global cancer incidence and mortality in 2018: GLOBOCAN sources and methods. Int J Cancer. (2018) 144:1941-53. doi: $10.1002 /$ ijc. 31937

2. Labianca R, Beretta GD, Kildani B, Milesi L, Merlin F, Mosconi S, et al. Colon cancer. Crit Rev Oncol Hematol. (2010) 74:106-133. doi: 10.1016/j.critrevonc.2010.01.010

3. Qureshi A, Verma A, Ross P, Landau D. Colorectal cancer treatment. Clin Evid. (2010) 2010:401.

4. McWhirter D, Kitteringham N, Jones RP, Malik H, Park K, Palmer D. Chemotherapy induced hepatotoxicity in metastatic colorectal cancer: a review of mechanisms and outcomes. Crit Rev Oncol Hematol. (2013) 88:404-15. doi: 10.1016/j.critrevonc.2013.05.011

5. Rabik CA, Dolan ME. Molecular mechanisms of resistance and toxicity associated with platinating agents. Cancer Treat Rev. (2007) 33:9-23. doi: 10.1016/j.ctrv.2006.09.006

6. Ma X, Wang $\mathrm{Z}$. Anticancer drug discovery in the future: an evolutionary perspective. Drug Discov Today. (2009) 14:1136-42. doi: 10.1016/j.drudis.2009.09.006

7. Gordaliza M. Natural products as leads to anticancer drugs. Clin Transl Oncol. (2007) 9:767-76. doi: 10.1007/s12094-007-0138-9

8. Wang W, Ben-Daniel BH, Cohen Y. Control of plant diseases by extracts of Inula viscosa. Phytopathology. (2004) 94:1042-7. doi: 10.1094/PHYTO.2004.94.10.1042

9. Danino O, Gottlieb HE, Grossman S, Bergman M. Antioxidant activity of 1, 3-dicaffeoylquinic acid isolated from Inula viscosa. Food Res Int. (2009) 42:1273-80. doi: 10.1016/j.foodres.2009.03.023

10. Lauro L, Rolih C. Observations and research on an extract of Inula viscosa Ait. Boll Soc Ital Biol Sper. (1990) 66:829-34.

11. Talib WH, Mahasneh AM. Antiproliferative activity of plant extracts used against cancer in traditional medicine. Sci Pharm. (2010) 78:33-45. doi: 10.3797/scipharm.0912-11

12. Rozenblat S, Grossman S, Bergman M, Gottlieb H, Cohen Y, Dovrat S. Induction of $\mathrm{G} 2 / \mathrm{M}$ arrest and apoptosis by sesquiterpene lactones in human melanoma cell lines. Biochem Pharmacol. (2008) 75:369-82. doi: 10.1016/j.bcp.2007.08.024

13. Riccardi C, Nicoletti I. Analysis of apoptosis by propidium iodide staining and flow cytometry. Nat Protoc. (2006) 1:1458-61. doi: 10.1038/nprot.2006.238

14. Bradford MM. A rapid and sensitive method for the quantitation of microgram quantities of protein utilizing the principle of protein-dye binding. Anal Biochem. (1976) 72:248-54. doi: 10.1016/0003-2697(76)90527-3

15. Sánchez-Aragó M, Cuezva JM. The bioenergetic signature of isogenic colon cancer cells predicts the cell death response to treatment with 3bromopyruvate, iodoacetate or 5-fluorouracil. J Transl Med. (2011) 9:19. doi: $10.1186 / 1479-5876-9-19$

\section{AUTHOR CONTRIBUTIONS}

FF and RB-S designed the study and wrote the manuscript. RB-S performed the experiments and analyzed the data. $\mathrm{MB}$ and SG collected the plants and prepared the extract. NA and LS took part in the in vivo studies. All authors reviewed the draft manuscripts, read, and approved the final manuscript.

\section{ACKNOWLEDGMENTS}

We thank Dr. Sagie Schif-Zuck for the use of FACSCanto II (BD) equipment and the stuff of the animal house at the Technion Institute.

16. Krysko D V, Vanden Berghe T, D’Herde K, Vandenabeele P. Apoptosis and necrosis: detection, discrimination and phagocytosis. Methods. (2008) 44:205-21. doi: 10.1016/j.ymeth.2007.12.001

17. Vermes I, Haanen C, Reutelingsperger C. Flow cytometry of apoptotic cell death. J Immunol Methods. (2000) 243:167-90. doi: 10.1016/S0022-1759(00)00233-7

18. Newman DJ, Cragg GM. Natural products as sources of new drugs over the 30 years from 1981 to 2010. J Nat Prod. (2012) 75:311-35. doi: $10.1021 / \mathrm{np} 200906 \mathrm{~s}$

19. Patil SD. A recent review on anticancer herbal drugs. J drug Discov Ther. (2013) 1:77-84.

20. Kheyar-Kraouche N, da Silva AB, Serra AT, Bedjou F, Bronze MR. Characterization by liquid chromatography-mass spectrometry and antioxidant activity of an ethanolic extract of Inula viscosa leaves. J Pharm Biomed Anal. (2018) 156:297-306. doi: 10.1016/j.jpba.2018.04.047

21. Benbacer L, Merghoub N, El Btaouri H, Gmouh S, Attaleb M, Morjani H, et al. Antiproliferative effect and induction of apoptosis by Inula viscosa L. and Retama monosperma L. extracts in human cervical cancer cells. Top Cervical Cancer Advocacy Prev. (2012) 16:267-84. doi: 10.5772/30025

22. Merghoub N, Btaouri H, Benbacer L, Gmouh S, Trentesaux C, Brassart B, et al. Inula viscosa extracts induces telomere shortening and apoptosis in cancer cells and overcome drug resistance. Nutr Cancer. (2016) 68:131-43. doi: 10.1080/01635581.2016.1115105

23. Seca AML, Grigore A, Pinto DCGA, Silva AMS. The genus Inula and their metabolites: from ethnopharmacological to medicinal uses. J Ethnopharmacol. (2014) 154:286-310. doi: 10.1016/j.jep.2014.04.010

24. Mahmoudi H, Hosni K, Zaouali W, Amri I, Zargouni H, Hamida N Ben, et al. Comprehensive phytochemical analysis, antioxidant and antifungal activities of Inula viscosa aiton leaves. J Food Saf. (2016) 36:77-88. doi: $10.1111 /$ jfs. 12215

25. Maoz M, Neeman I. Antimicrobial effects of aqueous plant extracts on the fungi Microsporum canis and Trichophyton rubrum and on three bacterial species. Lett Appl Microbiol. (1998) 26:61-3. doi: 10.1046/j.1472-765X.1998.00277.x

26. Ali-Shtayeh MS, Yaghmour RM, Faidi YR, Salem K, Al-Nuri MA. Antimicrobial activity of 20 plants used in folkloric medicine in the Palestinian area. J Ethnopharmacol. (1998) 60:265-71. doi: 10.1016/S0378-8741(97)00153-0

27. Brahmi-Chendouh N, Piccolella S, Crescente G, Pacifico F, Boulekbache L, Hamri-Zeghichi $\mathrm{S}$, et al. A nutraceutical extract from Inula viscosa leaves: UHPLC-HR-MS/MS based polyphenol profile, and antioxidant and cytotoxic activities. J Food Drug Anal. (2019). doi: 10.1016/j.jfda.2018.11.006. [Epub ahead of print].

28. Gonzalez-Vallinas M, Gonzalez-Castejon M, Rodriguez-Casado A, Ramirez de Molina A. Dietary phytochemicals in cancer prevention and therapy: a complementary approach with promising perspectives. Nutr Rev. (2013) 71:585-99. doi: 10.1111/nure.12051 
29. Yin T-F, Min Wang YQ, Lin Y-M, Wu D. Research progress on chemopreventive effects of phytochemicals on colorectal cancer and their mechanisms. World J Gastroenterol. (2016) 22:7058-68. doi: 10.3748/wjg.v22.i31.7058

30. Ramos S. Effects of dietary flavonoids on apoptotic pathways related to cancer chemoprevention. J Nutr Biochem. (2007) 18:427-42. doi: 10.1016/j.jnutbio.2006.11.004

31. Kim M, Miyamoto S, Yasui Y, Oyama T, Murakami A, Tanaka T. Zerumbone, a tropical ginger sesquiterpene, inhibits colon and lung carcinogenesis in mice. Int J Cancer. (2009) 124:264-71. doi: 10.1002/ijc.23923t

32. Prasad S, Gupta SC, Tyagi AK. Reactive oxygen species (ROS) and cancer: role of antioxidative nutraceuticals. Cancer Lett. (2017) 387:95-105. doi: 10.1016/j.canlet.2016. 03.042

33. Bergman M, Varshavsky L, Gottlieb HE, Grossman S. The antioxidant activity of aqueous spinach extract: chemical identification of active fractions. Phytochemistry. (2001) 58:143-52. doi: 10.1016/S0031-9422(01)00137-6

34. Khan N, Afaq F, Saleem M, Ahmad N, Mukhtar H. Targeting multiple signaling pathways by green tea polyphenol (-)-epigallocatechin-3-gallate. Cancer Res. (2006) 66:2500-5. doi: 10.1158/0008-5472.CAN-05-3636

35. Belayachi L, Aceves-Luquero C, Merghoub N, Bakri Y, Fernández de Mattos S, Amzazi S, et al. Screening of North African medicinal plant extracts for cytotoxic activity against tumor cell lines. Eur J Med Plants. (2013) 3:310-32. doi: 10.9734/EJMP/2013/3403

36. Pal HC, Sehar I, Bhushan S, Gupta BD, Saxena AK. Activation of caspases and poly (ADP-ribose) polymerase cleavage to induce apoptosis in leukemia HL-60 cells by Inula racemosa. Toxicol Vitr. (2010) 24:1599-609. doi: 10.1016/j.tiv.2010.06.007

37. Russo P, Malacarne D, Falugi C, Trombino S, O'Connor PM. RPR-115135, a farnesyltransferase inhibitor, increases 5-FU-cytotoxicity in ten human colon cancer cell lines: role of p53. Int J Cancer. (2002) 100:266-75. doi: 10.1002/ijc.10461

38. Fischer M, Quaas M, Steiner L, Engeland K. The p53-p21-DREAM-CDE/CHR pathway regulates G2/M cell cycle genes. Nucleic Acids Res. (2016) 44:164-74. doi: 10.1093/nar/gkv927

39. Murakami Y, Hayashi K, Sekiya T. Detection of aberrations of the p53 alleles and the gene transcript in human tumor cell lines by singlestrand conformation polymorphism analysis. Cancer Res. (1991) 51: 3356-61.

40. Fulda S, Debatin KM. Extrinsic versus intrinsic apoptosis pathways in anticancer chemotherapy. Oncogene. (2006) 25:4798-811. doi: 10.1038/sj.onc.1209608

41. Smulson ME, Simbulan-Rosenthal CM, Boulares AH, Yakovlev A, Stoica B, Iyer S, et al. Roles of poly(ADP-ribosyl)ation and PARP in apoptosis, DNA repair, genomic stability and functions of p53 and E2F1. Adv Enzyme Regul. (2000) 40:183-215. doi: 10.1016/S0065-2571(99) 00024-2
42. Lan Y-H, Chiang J-H, Huang W-W, Lu C-C, Chung J-G, Wu T$\mathrm{S}$, et al. Activations of both extrinsic and intrinsic pathways in HCT 116 human colorectal cancer cells contribute to apoptosis through p53mediated ATM/Fas signaling by Emilia sonchifolia extract, a folklore medicinal plant. Evid Based Complement Altern Med. (2012) 2012:178178. doi: $10.1155 / 2012 / 178178$

43. Derry M, Raina K, Agarwal R, Agarwal C. Differential effects of grape seed extract against human colorectal cancer cell lines: the intricate role of death receptors and mitochondria. Cancer Lett. (2012) 334:69-78. doi: 10.1016/j.canlet.2012.12.015

44. Li M, Song L-H, Yue GG-L, Lee JK-M, Zhao L-M, Li L, et al. Bigelovin triggered apoptosis in colorectal cancer in vitro and in vivo via upregulating death receptor 5 and reactive oxidative species. Sci Rep. (2017) 7:42176. doi: $10.1038 /$ srep42176

45. Wang G-W, Qin J-J, Cheng X-R, Shen Y-H, Shan L, Jin H-Z, et al. Inula sesquiterpenoids: structural diversity, cytotoxicity and anti-tumor activity. Expert Opin Investig Drugs. (2014) 23:317-45. doi: $10.1517 / 13543784.2014 .868882$

46. Kamei H, Koide T, Kojimam T, Hasegawa M, Terabe K, Umeda T, et al. Flavonoid-mediated tumor growth suppression demonstrated by in vivo study. Cancer Biother Radiopharm. (1996) 11:193-6. doi: 10.1089/cbr.1996.11.193

47. Ren W, Qiao Z, Wang H, Zhu L, Zhang L. Flavonoids: promising anticancer agents. Med Res Rev. (2003) 23:519-34. doi: 10.1002/med.10033

48. de Jonge MJA, Verweij J. Renal toxicities of chemotherapy. Semin Oncol. (2006) 33:68-73. doi: 10.1053/j.seminoncol.2005.11.011

49. Ramadori G, Cameron S. Effects of systemic chemotherapy on the liver. Ann Hepatol. (2010) 9:133-43.

50. Rubbia-Brandt L, Audard V, Sartoretti P, Roth AD, Brezault C, Le Charpentier $M$, et al. Severe hepatic sinusoidal obstruction associated with oxaliplatinbased chemotherapy in patients with metastatic colorectal cancer. Ann Oncol. (2004) 15:460-6. doi: 10.1093/annonc/mdh095

51. Dunn SR, Qi Z, Bottinger EP, Breyer MD, Sharma K. Utility of endogenous creatinine clearance as a measure of renal function in mice. Kidney Int. (2004) 65:1959-67. doi: 10.1111/j.1523-1755.2004.00600.x

Conflict of Interest Statement: The authors declare that the research was conducted in the absence of any commercial or financial relationships that could be construed as a potential conflict of interest.

Copyright (c) 2019 Bar-Shalom, Bergman, Grossman, Azzam, Sharvit and Fares. This is an open-access article distributed under the terms of the Creative Commons Attribution License (CC BY). The use, distribution or reproduction in other forums is permitted, provided the original author(s) and the copyright owner(s) are credited and that the original publication in this journal is cited, in accordance with accepted academic practice. No use, distribution or reproduction is permitted which does not comply with these terms. 